\title{
Disturbed acid-base transport: an emerging cause of hypertension
}

\section{Ebbe Boedtkjer * and Christian Aalkjaer}

Department of Biomedicine, Aarhus University, Aarhus, Denmark

\section{Edited by:}

Mark O. Bevensee, University of Alabama at Birmingham, USA

\section{Reviewed by:}

Ignacio Gimenez, Aragon's Health Sciences Institute, Spain

Susan M. Wall, Emory University School of Medicine, USA

\section{${ }^{*}$ Correspondence:}

Ebbe Boedtkier, Department of Biomedicine, Aarhus University, Ole Worms Allé 6, building 1180, DK-8000 Aarhus C, Denmark e-mail: eb@fi.au.dk
Genome-wide association studies and physiological investigations have linked alterations in acid-base transporters to hypertension. Accordingly, $\mathrm{Na}^{+}$-coupled $\mathrm{HCO}_{3}^{-}$-transporters, $\mathrm{Na}^{+} / \mathrm{H}^{+}$-exchangers, and anion-exchangers have emerged as putative mechanistic components in blood pressure disturbances. Even though hypertension has been studied extensively over the last several decades, the cause of the high blood pressure has in most cases not been identified. Renal, cardiovascular, and neuronal dysfunctions all seem to play a role in hypertension development but their relative importance and mutual interdependency are still being debated. Multiple functional and structural alterations have been described in patients and animals with hypertension but it is typically unclear whether they are causes or consequences of hypertension or represent mechanistically unrelated associations. Perturbed blood pressure regulation has been demonstrated in several animal models with disrupted expression of acid-base transporters; and reciprocally, disturbed acid-base transport function has been described in hypertensive individuals. In addition to regulating intracellular and extracellular $\mathrm{pH}, \mathrm{Na}^{+}$-coupled $\mathrm{HCO}_{3}^{-}$-transport, $\mathrm{Na}^{+} / \mathrm{H}^{+}$-exchange, and anion-exchange also contribute to water and electrolyte balance in cells and systemically. Since acid-base transporters are widely expressed, alterations in transport activities likely affect multiple cell and organ functions, and it is a significant challenge to determine the mechanisms linking perturbed acid-base transport function to hypertension. It is the purpose of this review to evaluate the current evidence for involvement of acid-base transporters in hypertension development and discuss the cellular and integrative mechanisms, which may link changes in acid-base transport to blood pressure disturbances.

Keywords: blood pressure, SLC4, SLC9, SLC26, intracellular pH, acidosis, alkalosis

\section{INTRODUCTION}

Around $40 \%$ of the adult population has hypertension (WHO, 2013), and although the cause of the high blood pressure is typically unknown, it is well established that hypertension is a leading cause of e.g., ischemic heart disease, stroke, and renal disease. Consequently, hypertension has detrimental effects on human health and severe socioeconomic consequences.

Blood pressure control takes place through a complex interplay between multiple organ systems. The mean perfusion pressure of the systemic circulation is determined by the product of the cardiac output and the peripheral vascular resistance; and consequently, the blood pressure depends on e.g., the cardiac contractile function, the circulating blood volume, the vascular smooth muscle and endothelial function in resistance arteries, the vascular structure, the viscosity of the blood, the secretory function of endocrine glands, and the sympathetic nervous tone. In line with the complex nature of blood pressure regulation, multiple mechanisms of deregulation have been proposed; and as described by Page's mosaic theory, essential hypertension in most cases is likely to be a multifactorial disease involving several organ systems in a complex interplay (Page, 1949). In some cases, however, these diverse changes may have a common denominator such as changes in oxidative stress or immune cell function
(Harrison, 2013). Frequently described causes for hypertension involve changes in the kidneys, the resistance vasculature, and the autonomic nervous system. As discussed in further detail below, the function of these organs all depends on appropriate levels of membrane acid-base transport activity. In congruence, over the last few decades, several experimental investigations and genetic association studies have proposed that alterations in the expression and function of acid-base transporters can be involved in blood pressure deregulation (Table 1). For the most part, however, the mechanistic background linking disturbed acid-base transport activity to hypertension is unknown, and it is the scope of the current review to summarize and discuss possible pathophysiological mechanisms.

\section{GENETIC ASSOCIATION STUDIES}

Multiple associations between genetic polymorphisms in acidbase transporters and disturbed blood pressure regulation have been described (Table 1). These studies propose that anionexchangers (AE1, AE2), $\mathrm{Na}^{+}, \mathrm{HCO}_{3}^{-}$-cotransporters (NBCe1, $\mathrm{NBCe} 2, \mathrm{NBCn} 1$ ) and $\mathrm{Na}^{+} / \mathrm{H}^{+}$-exchangers (NHE2, NHE3) can be involved in hypertension development. It should be noted that for several of the single nucleotide polymorphisms (SNPs), which have been shown to correlate with hypertension in some studies, 
Table 1 | Genetic and experimental associations between acid-base transporters and blood pressure.

\begin{tabular}{|c|c|c|c|}
\hline Gene name & $\begin{array}{l}\text { SNP/locus/ } \\
\text { modification }\end{array}$ & Phenotype & References \\
\hline \multirow[t]{2}{*}{ SLC4A1 } & rs5036 & Hypertension & Kokubo et al., 2006 \\
\hline & rs2857078 & Preeclampsia & $\begin{array}{l}\text { Morrison et al., } \\
2010\end{array}$ \\
\hline$S L C 4 A 2$ & rs2303934 & Hypertension & Sõber et al., 2009 \\
\hline$S L C 4 A 4$ & SNP & Hypertension & Yang et al., 2012 \\
\hline \multirow[t]{2}{*}{$S L C 4 A 5$} & $\begin{array}{l}\text { rs7571842 } \\
\text { rs10177833 } \\
\text { rs8179526 } \\
\text { hcv1137534 }\end{array}$ & $\begin{array}{l}\text { Salt-sensitive } \\
\text { hypertension }\end{array}$ & $\begin{array}{l}\text { Barkley et al., } \\
\text { 2004; Hunt et al., } \\
\text { 2006; Taylor et al., } \\
\text { 2009, 2012, 2013; } \\
\text { Carey et al., } 2012\end{array}$ \\
\hline & Knockout & Hypertension & Gröger et al., 2012 \\
\hline \multirow[t]{2}{*}{ SLC4A7 } & rs13082711 & Hypertension & Ehret et al., 2011 \\
\hline & Knockout & $\begin{array}{l}\text { Resting } \\
\text { hypertension but } \\
\text { protected } \\
\text { against } \\
\text { hypertension to } \\
\text { Ang-II and } \\
\text { L-NAME }\end{array}$ & $\begin{array}{l}\text { Boedtkjer et al., } \\
2011\end{array}$ \\
\hline \multirow[t]{2}{*}{ SLC9A1 } & Knockout & Hypotension & $\begin{array}{l}\text { Boedtkjer et al., } \\
2012\end{array}$ \\
\hline & Knockout & $\begin{array}{l}\text { Protection } \\
\text { against } \\
\text { pulmonary } \\
\text { hypertension }\end{array}$ & Yu et al., 2008 \\
\hline SLC9A2 & $\begin{array}{l}\text { SNP No. } 4 \\
\text { (intron 6) }\end{array}$ & Hypertension & Iwai et al., 2006 \\
\hline \multirow[t]{2}{*}{ SLC9A3 } & rs4957061 & Preeclampsia & $\begin{array}{l}\text { Morrison et al., } \\
2010\end{array}$ \\
\hline & Knockout & Hypotension & $\begin{array}{l}\text { Schultheis et al., } \\
\text { 1998; Noonan } \\
\text { et al., } 2005\end{array}$ \\
\hline \multirow[t]{2}{*}{ SLC26A4 } & Knockout & $\begin{array}{l}\text { Protection } \\
\text { against } \\
\text { mineralocorticoid- } \\
\text { induced } \\
\text { hypertension }\end{array}$ & $\begin{array}{l}\text { Verlander et al., } \\
2003\end{array}$ \\
\hline & Overexpression & $\begin{array}{l}\mathrm{Cl}^{-} \text {-sensitive } \\
\text { hypertension }\end{array}$ & Jacques et al., 2013 \\
\hline SLC26A6 & Knockout & $\begin{array}{l}\text { Protected } \\
\text { against } \\
\text { fructose-induced } \\
\text { hypertension }\end{array}$ & Singh et al., 2008 \\
\hline SLC26A9 & Knockout & Hypertension & Amlal et al., 2013 \\
\hline
\end{tabular}

other studies have not been able to confirm the association. This may in part be due to differences in the investigated population sizes but may also reflect differences in e.g., ethnicities, gender, age or co-morbidity - which considering the complexity of blood pressure regulation may modify the effects of specific gene variants. Depending on the location of the SNPs, it is possible that they can alter the function or the expression of the transporters, but in many circumstances the SNPs described to associate with hypertension may not themselves be causative but rather be in linkage disequilibrium with functionally important SNPs residing within the coding region or in important gene regulatory elements.

While the observed genetic associations do not themselves provide mechanistic insight, they are important in elucidating new targets to be studied experimentally. In some cases, experimental investigations support the link between the acid-base transporters and hypertension and provide evidence for a pathophysiological mechanism. The importance of NBCn1 for blood pressure regulation was for instance proposed by a recent genome-wide association study linking the rs 13082711 SNP located $10 \mathrm{~kb} 5^{\prime}$ of the coding region of SLC4A7 to hypertension (Ehret et al., 2011), and this finding was concurrently reinforced by an experimental study showing that NBCn1 knockout mice have a complex blood pressure phenotype and an altered vascular function (Boedtkjer et al., 2011), see section The Resistance Arteries and Microvasculature. Likewise, multiple studies linking SNPs in SLC4A5 to salt-sensitive hypertension (Barkley et al., 2004; Hunt et al., 2006; Taylor et al., 2009, 2012, 2013; Carey et al., 2012) have been supported by the finding that knockout mice for NBCe 2 are hypertensive (Gröger et al., 2012), see section The Kidneys.

\section{THE KIDNEYS}

The kidneys have classically been considered the primary organs for long-term regulation of blood pressure (Guyton, 1991). The proposed mechanism of renal blood pressure regulation involves a feedback system where an excess arterial pressure causes the kidneys to excrete more salt and water, decreasing the circulating blood volume, and ultimately reducing the blood pressure (Guyton, 1991). The relationship between arterial pressures and urinary salt output has been suggested to be exceptionally steep and the system has been proposed to have infinite feedback gain (Guyton, 1991), i.e., it is able to fully compensate any deviation in blood pressure away from the set-point. This dominating role of the kidneys for blood pressure regulation has more recently been investigated in a series of elegant experiments using transgenic mice. Focusing specifically on the impact of the renin angiotensin system, reciprocal cross-transplantations of fully vascularized kidney transplants between AT1A receptor deficient and wild type mice were performed to determine the relative importance of AT1A receptors expressed in renal (e.g., the renal epithelium, the renal vasculature or other renal components) and extra-renal (e.g., the resistance vasculature, the CNS or the adrenals) tissues for baseline blood pressure and angiotensin II induced hypertension. These studies support that the hypertensive effects of angiotensin II are predominantly dependent on renal AT1A receptors (Crowley et al., 2006). In contrast, the reduced resting blood pressure observed in AT1A deficient 
mice was found to depend approximately equally on renal and extra-renal AT1A receptors (Crowley et al., 2005). Although subsequent experiments have shown that selective inactivation of signaling pathways in the vascular wall can protect against hypertension development (see section The Resistance Arteries and Microvasculature), these findings support that the kidneys play a prominent-although not exclusive-role for blood pressure regulation and hypertension development.

As described above, the kidneys contribute to blood pressure regulation by modulating body water and electrolyte homeostasis through the control of urinary excretion. Simplistically, enhanced $\mathrm{Na}^{+}$and water retention by the kidneys is expected to increase the circulating blood volume, increase the venous return to the heart—and through the Frank-Starling mechanism- to raise the stroke volume, cardiac output, and blood pressure. However, while an increased cardiac output has been reported in the early phases of essential hypertension, cardiac output has been described to be normal in patients with sustained essential hypertension (Lund-Johansen, 1991). Thus, there seems to be a shift in hypertensive patients from an early phase with a hyperkinetic circulation (i.e., increased cardiac output) to an established phase with an increased total peripheral resistance and a normal cardiac output. The importance of an increased peripheral resistance for hypertension induced by salt retention has recently been supported by the finding that smooth muscle specific abrogation of the myosin light chain kinase (He et al., 2011) or the G-protein coupled pathways required for activation of the rho-kinase (Wirth et al., 2008) attenuates the development of deoxycorticosterone acetate (DOCA)-salt hypertension. Although the mechanisms linking disturbed renal salt and water handling and increased circulating blood volume to an increased peripheral vascular resistance remain controversial, it is well-documented that renal $\mathrm{Na}^{+}$retention leads to hypertension. Acid-base transporters may play a very significant role both in mediating renal $\mathrm{Na}^{+}$retention (see below) and in modifying the subsequent increase in peripheral vascular resistance (see section The Resistance Arteries and Microvasculature).

Acid-base transporters are expressed in all segments of the nephrons and collecting ducts; and since the actions of many acid-base transporters involve co- or counter-transport of $\mathrm{Na}^{+}$ and/or $\mathrm{Cl}^{-}$, they can directly influence renal $\mathrm{NaCl}$ handling. A detailed description of the expression patterns and functional roles of acid-base transporters in the different renal tubular segments is outside the scope of the current review but the potential role of $\mathrm{Na}^{+}$-coupled acid-base transporters for blood pressure regulation is exemplified by the $\mathrm{Na}^{+} / \mathrm{H}^{+}$-exchanger NHE3 (Slc9a3): this transporter-which is expressed in renal proximal tubules, some thin descending limbs, and in the thick ascending limbs of the loop of Henle-has been shown to play a major role for renal $\mathrm{Na}^{+}$reabsorption, and in congruence, under low to normal $\mathrm{NaCl}$ intake, NHE3 knockout mice are hypotensive (Schultheis et al., 1998; Noonan et al., 2005). Similarly, transport of acid-base equivalents coupled to $\mathrm{Cl}^{-}$has been convincingly shown to modify blood pressure: knockout of the anion-exchanger pendrin (Slc26a4), which contributes to $\mathrm{Cl}^{-}$reabsorption in the distal nephron (Wall et al., 2004), has been shown to protect against mineralocorticoid-induced hypertension (Verlander et al., 2003) while overexpression of pendrin in the intercalated cells was recently shown to cause hypertension (Jacques et al., 2013). It should be noted that both direct effects of increased or reduced acid-base transporter activity as well as compensatory effects of altered delivery of acid-base, $\mathrm{Na}^{+}$or $\mathrm{Cl}^{-}$loads to downstream tubule segments may contribute to changes in electrolyte homeostasis and blood pressure deregulation. Although further experimental evidence is required to test this hypothesis, it has for instance been suggested that knockout of NBCe2-which is expressed in the renal collecting ducts (Damkier et al., 2007; Gröger et al., 2012)—causes hypertension because of a compensatory increase in $\mathrm{NBCn} 1$ transport activity (Gröger et al., 2012). NBCn1 is expressed in the renal medullary collecting ducts (Boedtkjer et al., 2008) and due to the $1: 1 \mathrm{Na}^{+}$to $\mathrm{HCO}_{3}^{-}$stoichiometry of $\mathrm{NBCn} 1$ rather than the 1:2 stoichiometry of NBCe2, the putative shift from NBCe2- to NBCn1-mediated $\mathrm{HCO}_{3}^{-}$reabsorption could increase the concomitant $\mathrm{Na}^{+}$reabsorption and contribute to the raised blood pressure (Gröger et al., 2012). Consistent with the involvement of renal $\mathrm{Na}^{+}$retention in the hypertensive phenotype of NBCe2 deficient mice, two of the SLC4A5 SNPs associated with hypertension in humans were also found to associate with salt-sensitivity of the raised blood pressure (Carey et al., 2012).

In addition to direct effects of the $\mathrm{Na}^{+}$- or $\mathrm{Cl}^{-}$-coupled acidbase transporters on renal salt retention, changes in intracellular acid-base balance in the renal epithelium are also likely to affect other transport systems: numerous ion channels [e.g., the ROMK $\mathrm{K}^{+}$-channel (Wang et al., 1990; Fakler et al., 1996; Choe et al., 1997)] and transporters [e.g., the $\mathrm{Na}^{+} / \mathrm{K}^{+}$-ATPase (Russell et al., 1983; Eaton et al., 1984; Breitwieser et al., 1987)] are modulated by the local $\mathrm{pH}$ and may therefore, contribute to salt retention or wasting as a consequence of disturbed intracellular $\mathrm{pH}$ control.

Consistent with an association between acid-base transporters and blood pressure regulation, altered renal expression levels and acid-base transport function have been reported in hypertension: $\mathrm{Na}^{+} / \mathrm{H}^{+}$-exchange activity has been shown to be increased in brush border membranes of proximal tubules from spontaneously hypertensive compared to Wistar-Kyoto rats (Morduchowicz et al., 1989; Gesek and Schoolwerth, 1991; Dagher and Sauterey, 1992; Hayashi et al., 1997). Whether this functional difference is explained by an increased expression of NHE3 in spontaneously hypertensive rats is controversial (Hayashi et al., 1997; Sonalker et al., 2004) but the increased $\mathrm{Na}^{+} / \mathrm{H}^{+}$-exchange activity may also be related to a lower expression of the regulatory protein NHERF1 (Kobayashi et al., 2004). $\mathrm{Na}^{+}, \mathrm{HCO}_{3}^{-}$-cotransport has also been found to be altered in hypertensive animals; however, the increased NBCel expression reported in the renal cortex of spontaneously hypertensive compared to Wistar-Kyoto rats (Sonalker et al., 2004) was not confirmed in experiments using immortalized proximal tubular epithelial cells, which showed lower NBCel expression and $\mathrm{Na}^{+}, \mathrm{HCO}_{3}^{-}$-cotransport activity in cells from spontaneously hypertensive compared to Wistar-Kyoto rats (Pedrosa et al., 2007). The expression of both NBCe1 and NHE3 has been found to be increased in the renal cortex of rats with noradrenalineinduced hypertension (Sonalker et al., 2008). Although it is currently unclear whether these changes in acid-base transporter 
expression and function are causative, compensatory or unrelated to the blood pressure disturbances, they warrant further experimental study to elucidate their mechanistic relevance.

\section{THE RESISTANCE ARTERIES AND MICROVASCULATURE}

The resistance vasculature plays a central role in regulating peripheral vascular resistance and blood pressure in the short term, but it has been debated whether primary changes in the vascular wall can be responsible for sustained blood pressure disturbances: based on the suggestion by Guyton that the renal regulation of fluid balance has infinite gain, it has been argued that a blood pressure rise in response to vasoconstriction will elicit an enhanced renal water and salt excretion, which will ultimately normalize blood pressure (Guyton, 1990). As a consequence, long-term blood pressure disturbances should be possible only if renal fluid control is affected either directly or in response to changes in renal artery function (Guyton, 1990). Supporting a role for the vasculature in long-term regulation of blood pressure, pharmacological agents (e.g., $\mathrm{Ca}^{2+}$ channel blockers) thought to act primarily on the vascular smooth muscle cells have sustained blood pressure lowering effects (Fleckenstein et al., 1985); and over recent years, genetic modifications specific to cells of the vascular wall have been shown to modify blood pressure. Smooth muscle specific inactivation of Arhgef 1 or $\mathrm{G}_{12}-\mathrm{G}_{13}$-LARG, important for rho-kinase signaling, was for instance shown to protect against hypertension development during chronic angiotensin II infusion and DOCA-salt treatment (Wirth et al., 2008; Guilluy et al., 2010) while smooth muscle specific deletion of the NOactivated soluble guanylyl cyclase (Groneberg et al., 2010) or endothelium-specific expression of a dominant negative peroxisome proliferator-activated receptor (PPAR) $\gamma$ (Pelham et al., 2013) was found to cause hypertension. Also, smooth muscle specific deletion of Dicer (Albinsson et al., 2011), which is required for microRNA processing, or of the $\mathrm{Na}^{+} / \mathrm{Ca}^{2+}$-exchanger (Zhang et al., 2010) was shown to cause hypotension. Although the ability of vasoactive drugs and vascular genetic modifications to change blood pressure in the long term may be explained by actions on the renal arteries and therefore, ultimately depend on altered renal fluid handling, these findings demonstrate that primary modifications of vascular function can alter blood pressure and that these effects are not fully corrected by compensatory changes in renal excretory function.

The impact of extracellular acid-base disturbances on the function of resistance arteries has long been appreciated; and while the mechanistic background is not comprehensively understood, extracellular acid-base disturbances are assumed to contribute substantially to the metabolic regulation of blood flow. As a consequence of extracellular acid-base disturbances or as independent disorders, the intracellular acid-base balance can be altered in a number of disease conditions and probably as a result of genetic polymorphisms or mutations in acid-base transporters. As recently reviewed in detail (Boedtkjer and Aalkjaer, 2012), intracellular acid-base disturbances have major effects on contractile and relaxant functions of resistance arteries. Three transport systems dedicated to movement of acid-base equivalents have been described in the plasma membrane of vascular smooth muscle and endothelial cells: acid extrusion is mediated by the electroneutral $\mathrm{Na}^{+}, \mathrm{HCO}_{3}^{-}$-cotransporter $\mathrm{NBCn} 1$ (Aalkjaer and Hughes, 1991; Boedtkjer et al., 2006, 2011; Thomsen et al., 2013) and the $\mathrm{Na}^{+} / \mathrm{H}^{+}$-exchanger NHE1 (Boedtkjer and Aalkjaer, 2009; Boedtkjer et al., 2012), while base extrusion is mediated by $\mathrm{Cl}^{-} / \mathrm{HCO}_{3}^{-}$-exchange (Aalkjaer and Hughes, 1991; Boedtkjer et al., 2013). Whereas both NBCn1 and NHE1 contribute to cellular acid extrusion during intracellular acidification, $\mathrm{NBCn} 1$ is the primary acid extrusion mechanism important for control of resting steady-state intracellular $\mathrm{pH}$ in both vascular smooth muscle and endothelial cells (Boedtkjer et al., 2011, 2012). Hence, knockout of NHE1 affects steady-state intracellular $\mathrm{pH}$ only in the absence of $\mathrm{CO}_{2} / \mathrm{HCO}_{3}^{-}$(Boedtkjer et al., 2012).

We recently showed that knockout of NBCn1 has severe consequences for blood pressure regulation in mice: NBCn1 knockout mice are moderately hypertensive at rest $(\sim 10 \mathrm{mmHg})$ but show reduced blood pressure increases to NO-synthase inhibition and angiotensin II infusion (Boedtkjer et al., 2011). Association between genetic polymorphisms in $\mathrm{NBCn} 1$ and human hypertension has also been demonstrated (Ehret et al., 2011), see section Genetic Association Studies. Consistent with the changes in blood pressure regulation, we showed that sustained intracellular acidification of endothelial cells, whether induced by knockout of $\mathrm{NBCn} 1$ (in the presence of $\mathrm{CO}_{2} / \mathrm{HCO}_{3}^{-}$) or NHE1 (in the absence of $\mathrm{CO}_{2} / \mathrm{HCO}_{3}^{-}$), inhibits basal and acetylcholinestimulated NO synthesis and vasorelaxation (Boedtkjer et al., 2011, 2012; Thomsen et al., 2013). In addition, sustained acidification of vascular smooth muscle cells induced by similar approaches inhibits rho-kinase-dependent $\mathrm{Ca}^{2+}$-sensitivity and attenuates myogenic responsiveness and vasoconstriction to noradrenaline (Boedtkjer et al., 2011, 2012; Thomsen et al., 2013). The combination of anti-contractile and anti-relaxant effects of low intracellular $\mathrm{pH}$ in the vascular wall likely explains the complex blood pressure phenotype of the NBCn1 knockout mice, which depending on the activity in the affected signaling pathways under certain conditions display higher and under other conditions lower blood pressure than wild type mice (Boedtkjer et al., 2011). Adding to the complexity, the anti-contractile effect of low intracellular $\mathrm{pH}$ in the vascular smooth muscle cells is evident during sustained (i.e., lasting several minutes to hours) intracellular acidification (Boedtkjer et al., 2006, 2011, 2012), whereas acute (i.e., taking place within a few tens of seconds) intracellular acidification causes abrupt vasoconstriction (Aalkjaer and Mulvany, 1988) probably due to competition between $\mathrm{H}^{+}$and $\mathrm{Ca}^{2+}$ for buffer binding (Abercrombie and Hart, 1986; Batlle et al., 1993) and as a result of changes in cellular $\mathrm{Ca}^{2+}$ handling (Nielsen et al., 1991; Kozak et al., 2005; Restini and Bendhack, 2006). Under both physiological and pathological conditions, sustained changes in intracellular $\mathrm{pH}$ and associated anti-contractile effects are likely to predominate in vivo. Since contraction of vascular smooth muscle cells is associated with an increased intracellular acid load (Aalkjaer and Mulvany, 1991), it appears that a major role of membrane acid-base transport in these cells is to maintain intracellular $\mathrm{pH}$ at a sufficiently alkaline level that the $\mathrm{Ca}^{2+}$ sensitivity is not reduced. This may be particularly important during sustained contractions when the $\mathrm{Ca}^{2+}$. sensitivity of the vascular smooth muscle cells is usually increased (Boedtkjer et al., 2006). Supporting the importance of defending 
the intracellular $\mathrm{pH}$ of vascular smooth muscle cells during contractions, we have recently found that $\mathrm{NBCn} 1$ is activated in a calcineurin-dependent manner by the raised intracellular $\left[\mathrm{Ca}^{2+}\right]$ during depolarization or agonist-stimulation (Danielsen et al., 2013). In addition to the vasomotor effects of intracellular acidification, we have found that intracellular alkalinization of endothelial cells - induced by inhibition or reversal of anionexchange activity-impedes vasorelaxation by reducing intercellular coupling and endothelium-dependent hyperpolarizations (Boedtkjer et al., 2013). Although additional investigations are required to fully determine the pathophysiological significance of altered acid-base balance in the vascular wall, the recent evidence highlighted above strongly supports that $\mathrm{pH}$-induced changes in artery function should be considered a possible mechanistic component in cardiovascular disease.

Besides changes in artery function, it should be appreciated that changes in the structure of the vascular wall may contribute to blood pressure disturbances (Folkow et al., 1958; Sivertsson, 1970; Aalkjaer et al., 1987b). Increased media thickness in the resistance arteries is a characteristic finding in essential hypertension and carries independent prognostic value (Rizzoni et al., 2003; Mathiassen et al., 2007). Furthermore, changes in arterial media thickness has been reported in models of disturbed acid-base transport (Yu et al., 2008; Boedtkjer et al., 2012), but its putative mechanistic role for blood pressure deregulation is not comprehensively understood (Boedtkjer and Aalkjaer, 2013). Further evidence is required to determine the role of intracellular $\mathrm{pH}$ regulation for structural adaptation of the vascular wall but it should be noted that numerous studies on non-vascular cell types have demonstrated that acid-base transport particularly by NHE1 modifies cell proliferation and migration (Pedersen, 2006; Schwab et al., 2012), which are critical processes underlying structural plasticity. In addition to structural changes in the resistance arteries, the disappearance of capillaries and pre-capillary arterioles (a phenomenon known as rarefaction) is important for the development of hypertension (Humar et al., 2009) and could play a role in blood pressure disturbances induced by altered acidbase transport. Although endothelial dysfunction has been shown to be associated with micro-vascular rarefaction (Humar et al., 2009), the potential effects of intracellular acid-base disturbances in the vessel wall on angiogenesis and vessel remodeling need further investigation.

In additional support of a pathogenic role of acid-base transporters for hypertension development, evidence has been provided that $\mathrm{Na}^{+} / \mathrm{H}^{+}$-exchange activity is increased in vascular smooth muscle cells of arteries from spontaneously hypertensive rats compared to Wistar-Kyoto rats (Izzard and Heagerty, 1989; Scuteri et al., 1995; Orlov et al., 2000). Noteworthy, however, steady-state intracellular $\mathrm{pH}$ did not differ between the vascular smooth muscle cells from adult hypertensive and normotensive rats under physiological conditions, i.e., in the presence of $\mathrm{CO}_{2} / \mathrm{HCO}_{3}^{-}$(Izzard and Heagerty, 1989; Scuteri et al., 1995). Conversely, a difference in steady-state intracellular $\mathrm{pH}$ in the presence of $\mathrm{CO}_{2} / \mathrm{HCO}_{3}^{-}$was reported between young (5 weeks old) spontaneously hypertensive and Wistar-Kyoto rats, which may suggest that the effect of NHE1 over-activity is temporally variable and could be involved at an early critical time point when the blood pressure disturbance and abnormal artery structure develop (Izzard and Heagerty, 1989). Alternatively, it is possible that NHE1 affects the vascular structure through transportindependent mechanisms or changes in $\mathrm{pH}$ of local restricted spaces with no discernible effect on global intracellular $\mathrm{pH}$, as has been demonstrated in other cell types (Ro and Carson, 2004; Stock and Schwab, 2006). It is also possible that the vascular effects of NHE1 are secondary to changes in the function of other organ systems. The finding that NHE1 may act independently of global intracellular $\mathrm{pH}$ in the vascular smooth muscle cells is consistent with our previous data showing that arteries isolated from NHE1 knockout mice have reduced media thickness compared to arteries isolated from wild type mice despite no appreciable difference in steady-state intracellular $\mathrm{pH}$ in the presence of $\mathrm{CO}_{2} / \mathrm{HCO}_{3}^{-}$(Boedtkjer et al., 2012).

\section{THE CENTRAL AND AUTONOMIC NERVOUS SYSTEMS}

The regulation of sympathetic activity takes place through the cardiovascular center in the brain stem, which integrates multiple afferent inputs (e.g., from baroreceptors, chemoreceptors, and areas within the CNS) to control the autonomic output to e.g., the heart, kidneys, adrenals, and the resistance vasculature. The importance of afferent and efferent autonomic innervation for blood pressure control is underscored by the findings that renal denervation (Symplicity HTN-1 Investigators, 2011) or electric stimulation of the baroreceptors (Heusser et al., 2010) are promising treatment modalities for hypertensive patients not responding to conventional therapy.

Resistance arteries and veins in some vascular beds [e.g., the mesenteric (Birch et al., 2008)] are subject to intense sympathetic innervation while other vascular beds are without appreciable innervation and controlled primarily by local mechanical and metabolic factors. Increased sympathetic innervation of arteries has been reported in hypertensive rats (Mangiarua and Lee, 1990; Kunes et al., 1991), and it has been demonstrated that hypertension in spontaneously hypertensive rats can be prevented by reducing the sympathetic innervation (Brock et al., 1996). In humans, micro-neurography has been used to assess the sympathetic nervous activity, and an increased sympathetic nervous drive has been demonstrated in patients with essential hypertension and even in young ( $\sim 24$ years old $)$ individuals with borderline hypertension (Anderson et al., 1989). In experiments where spill-over of noradrenaline from sympathetic nerves was assessed, enhanced net-release of noradrenaline was found in patients with essential hypertension (Esler et al., 1981). In small arteries isolated from humans with essential hypertension, indirect evidence has been provided for an increased uptake of noradrenaline into nerve endings in the vascular wall, both in untreated individuals with essential hypertension (Aalkjaer et al., 1987b), in persons genetically predisposed for essential hypertension (Aalkjaer et al., 1987a), and in patients already receiving antihypertensive treatment (Aalkjaer et al., 1989). Although force development of isolated small arteries to stimulation of the intramural nerves has been shown to correlate negatively with blood pressure in a normotensive population (Nielsen et al., 1992), the current evidence points to sympathetic vasoconstriction as a contributor to the elevated peripheral resistance in essential 
hypertension and proposes that changes in sympathetic function is an early pathogenic change, which precedes the development of established essential hypertension.

Regulation of intracellular $\mathrm{pH}$ in the peripheral autonomic nervous system has not been investigated in any major detail but seems to have both $\mathrm{HCO}_{3}^{-}$-dependent and -independent components: in cultured sympathetic neurons, $\mathrm{Na}^{+} / \mathrm{H}^{+}$-exchange activity was suggested as the dominating acid extrusion mechanism, though $\mathrm{HCO}_{3}^{-}$-dependent acid extrusion was also found to enhance intracellular $\mathrm{pH}$ recovery after an intracellular acid load and to increase steady-state intracellular $\mathrm{pH}$ (Tolkovsky and Richards, 1987). $\mathrm{Na}^{+} / \mathrm{H}^{+}$-exchange is also a prominent mechanism of cellular acid extrusion in the central nervous system (Chesler and Nicholson, 1985). In addition, multiple $\mathrm{Na}^{+}$-dependent $\mathrm{HCO}_{3}^{-}$-transporters contribute to intracellular $\mathrm{pH}$ regulation in both neurons and glial cells: the $\mathrm{Na}^{+}$driven $\mathrm{Cl}^{-} / \mathrm{HCO}_{3}^{-}$-exchanger $\mathrm{NDCBE}$ was originally cloned from human brain (Grichtchenko et al., 2001); and functionally, $\mathrm{Na}^{+}$-dependent $\mathrm{Cl}^{-} / \mathrm{HCO}_{3}^{-}$-exchange has been shown to be prominent in both invertebrate neuronal tissue (Boron and De Weer, 1976; Russell and Boron, 1976; Thomas, 1976) and mammalian neurons and glia (Schwiening and Boron, 1994; Shrode and Putnam, 1994). Also the electroneutral $\mathrm{Na}^{+}, \mathrm{HCO}_{3}^{-}$cotransporter NBCn1 (Boedtkjer et al., 2008) and NCBE/NBCn2 (Chen et al., 2008) have been shown to be widely expressed in the cerebral and cerebellar cortex and in multiple subcortical regions. Consistent with high expression levels in the hippocampus (Boedtkjer et al., 2008), NBCn1 has been functionally demonstrated in cultured hippocampal neurons (Cooper et al., 2005). Furthermore, the electrogenic $\mathrm{Na}^{+}, \mathrm{HCO}_{3}^{-}$-cotransporter $\mathrm{NBCe} 1$ has been found to be prominently expressed in rat and mouse brain (Rickmann et al., 2007; Majumdar et al., 2008) and functionally demonstrated in both neurons (Svichar et al., 2011) and glia (Deitmer and Schlue, 1989). With respect to base extrusion, transcripts for multiple anion-exchangers have been detected in human brain (Havenga et al., 1994), and anionexchange activity has been demonstrated in glial cells (Bourke et al., 1978) and in neurons (Hentschke et al., 2006). Although the functional role of acid-base disturbances in the brain is not comprehensively understood, disturbed acid-base transport in neurons and glia has been suggested to contribute to activation of glycolysis in astrocytes (Ruminot et al., 2011) and protect against depolarization-induced acidification in neurons (Svichar et al., 2011). Furthermore, a pathophysiological significance of acidbase transport in the brain has been demonstrated by studies linking acid-base transport function to altered excitability (Bell et al., 1999; Hentschke et al., 2006; Jacobs et al., 2008) and neuronal cytotoxicity (Cooper et al., 2009). It is likely that changes in both local intracellular and extracellular $\mathrm{pH}$ play a role for the effects of the acid-base transporters; and while the functional role of acid-base balance for control of autonomic nervous function is presently unclear, the prominent acid-base transport mechanisms demonstrated in brain regions putatively involved in cardiovascular control underscores the need for studies investigating their mechanistic importance.

Interestingly, it has been proposed that increased $\mathrm{Na}^{+}$content in the body modifies sympathetic nervous activity and alters blood pressure due to a change in the concentration of $\mathrm{Na}^{+}$ in the cerebrospinal fluid (Blaustein et al., 2012). Transport of $\mathrm{Na}^{+}$into or out of the cerebrospinal fluid takes place largely through the choroid plexus and is partly mediated by acidbase transporters, including NHE1, AE2, NCBE/NBCn2, NBCn1, and NBCe2 (Damkier et al., 2010) providing a novel putative mechanism linking acid-base transport to blood pressure control.

\section{CONCLUSIONS}

Increasing evidence suggests that disturbed acid-base transport function may lead to clinically relevant changes in blood pressure and contribute to hypertension development. Although initial studies investigating the mechanistic link between acid-base transport and hypertension development are being conducted, we are still far from a comprehensive understanding. Additional studies are therefore required to determine to what extent altered acid-base transport function contributes to hypertension development in humans, whether these effects are due to changes in acid-base balance or dependent on the co- or counter-transported ions, which organ systems are primarily responsible for the changes in blood pressure, and whether the acid-base transport mechanisms can be exploited for future therapeutic intervention.

\section{ACKNOWLEDGMENTS}

Related work in the authors' laboratories was supported by the Danish Council for Independent Research (10-094816 to Ebbe Boedtkjer and 12-126232 to Christian Aalkjaer), the Lundbeck foundation (R93-A8859 to Ebbe Boedtkjer and R31-A2535 to Christian Aalkjaer) and the Novo Nordisk Foundation (to Ebbe Boedtkjer).

\section{REFERENCES}

Aalkjaer, C., Eiskjaer, H., Mulvany, M. J., Jespersen, B., Kjaer, T., Sorensen, S. S., et al. (1989). Abnormal structure and function of isolated subcutaneous resistance vessels from essential hypertensive patients despite antihypertensive treatment. J. Hypertens. 7, 305-310.

Aalkjaer, C., Heagerty, A. M., Bailey, I., Mulvany, M. J., and Swales, J. D. (1987a). Studies of isolated resistance vessels from offspring of essential hypertensive patients. Hypertension 9, III155-III158. doi: 10.1161/01.HYP.9.6_Pt_2.III155

Aalkjaer, C., Heagerty, A. M., Petersen, K. K., Swales, J. D., and Mulvany, M. J. (1987b). Evidence for increased media thickness, increased neuronal amine uptake, and depressed excitation-contraction coupling in isolated resistance vessels from essential hypertensives. Circ. Res. 61, 181-186. doi: 10.1161/01.RES.61.2.181

Aalkjaer, C., and Hughes, A. (1991). Chloride and bicarbonate transport in rat resistance arteries. J. Physiol. 436, 57-73.

Aalkjaer, C., and Mulvany, M. J. (1988). Effect of changes in intracellular pH on the contractility of rat resistance vessels. Prog. Biochem. Pharmacol. 23, 150-158.

Aalkjaer, C., and Mulvany, M. J. (1991). Steady-state effects of arginine vasopressin on force and $\mathrm{pH}_{i}$ of isolated mesenteric resistance arteries from rats. Am. J. Physiol. 261, C1010-C1017.

Abercrombie, R. F., and Hart, C. E. (1986). Calcium and proton buffering and diffusion in isolated cytoplasm from Myxicola axons. Am. J. Physiol. 250, C391-C405.

Albinsson, S., Skoura, A., Yu, J., DiLorenzo, A., Fernandez-Hernando, C., Offermanns, S., et al. (2011). Smooth muscle miRNAs are critical for post-natal regulation of blood pressure and vascular function. PLoS ONE 6:e18869. doi: 10.1371/journal.pone.0018869

Amlal, H., Xu, J., Barone, S., Zahedi, K., and Soleimani, M. (2013). The chloride channel/transporter Slc26a9 regulates the systemic arterial pressure and renal chloride excretion. J. Mol. Med. (Berl). 91, 561-572. doi: 10.1007/s00109-0120973-1 
Anderson, E. A., Sinkey, C. A., Lawton, W. J., and Mark, A. L. (1989). Elevated sympathetic nerve activity in borderline hypertensive humans. Evidence from direct intraneural recordings. Hypertension 14, 177-183. doi: 10.1161/01.HYP.14.2.177

Barkley, R. A., Chakravarti, A., Cooper, R. S., Ellison, R. C., Hunt, S. C., Province, M. A., et al. (2004). Positional identification of hypertension susceptibility genes on chromosome 2. Hypertension 43, 477-482. doi: 10.1161/01.HYP.0000111585.76299.f7

Batlle, D. C., Peces, R., LaPointe, M. S., Ye, M., and Daugirdas, J. T. (1993). Cytosolic free calcium regulation in response to acute changes in intracellular $\mathrm{pH}$ in vascular smooth muscle. Am. J. Physiol. 264, C932-C943.

Bell, S. M., Schreiner, C. M., Schultheis, P. J., Miller, M. L., Evans, R. L., Vorhees, C. V., et al. (1999). Targeted disruption of the murine Nhel locus induces ataxia, growth retardation, and seizures. Am. J. Physiol. 276, C788-C795.

Birch, D. J., Turmaine, M., Boulos, P. B., and Burnstock, G. (2008). Sympathetic innervation of human mesenteric artery and vein. J. Vasc. Res. 45, 323-332. doi $10.1159 / 000119095$

Blaustein, M. P., Leenen, F. H., Chen, L., Golovina, V. A., Hamlyn, J. M., Pallone, T. L., et al. (2012). How $\mathrm{NaCl}$ raises blood pressure: a new paradigm for the pathogenesis of salt-dependent hypertension. Am. J. Physiol. Heart Circ. Physiol. 302, H1031-H1049. doi: 10.1152/ajpheart.00899.2011

Boedtkjer, E., and Aalkjaer, C. (2009). Insulin inhibits $\mathrm{Na}^{+} / \mathrm{H}^{+}$exchange in vascular smooth muscle and endothelial cells in situ: involvement of $\mathrm{H}_{2} \mathrm{O}_{2}$ and tyrosine phosphatase SHP-2. Am. J. Physiol. Heart Circ. Physiol. 296, H247-H255. doi: 10.1152/ajpheart.00725.2008

Boedtkjer, E., and Aalkjaer, C. (2012). Intracelullar pH in the resistance vasculature: regulation and functional implications. J. Vasc. Res. 49, 479-496. doi $10.1159 / 000341235$

Boedtkjer, E., and Aalkjaer, C. (2013). Acid-base transporters modulate cell migration, growth and proliferation: implications for structure development and remodelling of resistance arteries? Trends Cardiovasc. Med. 23, 59-65. doi: 10.1016/j.tcm.2012.09.001

Boedtkjer, E., Damkier, H. H., and Aalkjaer, C. (2012). NHE1 knockout reduces blood pressure and arterial media/lumen ratio with no effect on resting $\mathrm{pH}_{i}$ in the vascular wall. J. Physiol. 590, 1895-1906. doi: 10.1113/jphysiol.2011.227132

Boedtkjer, E., Kim, S., and Aalkjaer, C. (2013). Endothelial alkalinisation inhibits gap junction communication and endothelium-derived hyperpolarisations in mouse mesenteric arteries. J. Physiol. 591, 1447-1461. doi: 10.1113/jphysiol. 2012.247478

Boedtkjer, E., Praetorius, J., and Aalkjaer, C. (2006). NBCn1 (slc4a7) mediates the $\mathrm{Na}^{+}$-dependent bicarbonate transport important for regulation of intracellular $\mathrm{pH}$ in mouse vascular smooth muscle cells. Circ. Res. 98, 515-523. doi 10.1161/01.RES.0000204750.04971.76

Boedtkjer, E., Praetorius, J., Fuchtbauer, E. M., and Aalkjaer, C. (2008). Antibodyindependent localization of the electroneutral $\mathrm{Na}^{+}-\mathrm{HCO}_{3}^{-}$cotransporter NBCn1 (slc4a7) in mice. Am. J. Physiol. Cell Physiol. 294, C591-C603. doi: 10.1152/ajpcell.00281.2007

Boedtkjer, E., Praetorius, J., Matchkov, V. V., Stankevicius, E., Mogensen, S., Füchtbauer, A. C., et al. (2011). Disruption of $\mathrm{Na}^{+}, \mathrm{HCO}_{3}^{-}$-cotransporter NBCn1 (slc4a7) inhibits NO-mediated vasorelaxation, smooth muscle $\mathrm{Ca}^{2+}$ sensitivity and hypertension development in mice. Circulation 124, 1819-1829. doi: 10.1161/CIRCULATIONAHA.110.015974

Boron, W. F., and De Weer, P. (1976). Active proton transport stimulated by $\mathrm{CO}_{2} / \mathrm{HCO}_{3}^{-}$, blocked by cyanide. Nature $259,240-241$. doi: 10.1038/259240a0

Bourke, R. S., Kimelberg, H. K., and Daze, M. A. (1978). Effects of inhibitors and adenosine on $\mathrm{HCO}_{3}^{-} / \mathrm{CO}_{2}$-stimulated swelling and $\mathrm{Cl}^{-}$uptake in brain slices and cultured astrocytes. Brain Res. 154, 196-202. doi: 10.1016/00068993(78)91072-7

Breitwieser, G. E., Altamirano, A. A., and Russell, J. M. (1987). Effects of pH changes on sodium pump fluxes in squid giant axon. Am. J. Physiol. 253 , C547-C554.

Brock, J. A., Van Helden, D. F., Dosen, P., and Rush, R. A. (1996). Prevention of high blood pressure by reducing sympathetic innervation in the spontaneously hypertensive rat. J. Auton. Nerv. Syst. 61, 97-102. doi: 10.1016/S01651838(96)00063-X

Carey, R. M., Schoeffel, C. D., Gildea, J. J., Jones, J. E., McGrath, H. E., Gordon, L. N., et al. (2012). Salt sensitivity of blood pressure is associated with polymorphisms in the sodium-bicarbonate cotransporter. Hypertension 60, 1359-1366. doi: 10.1161/HYPERTENSIONAHA.112.196071
Chen, L. M., Kelly, M. L., Rojas, J. D., Parker, M. D., Gill, H. S., Davis, B. A., et al. (2008). Use of a new polyclonal antibody to study the distribution and glycosylation of the sodium-coupled bicarbonate transporter NCBE in rodent brain. Neuroscience 151, 374-385. doi: 10.1016/j.neuroscience.2007.10.015

Chesler, M., and Nicholson, C. (1985). Regulation of intracellular $\mathrm{pH}$ in vertebrate central neurons. Brain Res. 325, 313-316. doi: 10.1016/0006-8993(85)90330-0

Choe, H., Zhou, H., Palmer, L. G., and Sackin, H. (1997). A conserved cytoplasmic region of ROMK modulates $\mathrm{pH}$ sensitivity, conductance, and gating. Am. J. Physiol. 273, F516-F529.

Cooper, D. S., Saxena, N. C., Yang, H. S., Lee, H. J., Moring, A. G., Lee, A., et al. (2005). Molecular and functional characterization of the electroneutral $\mathrm{Na} / \mathrm{HCO}_{3}$ cotransporter $\mathrm{NBCn} 1$ in rat hippocampal neurons. J. Biol. Chem. 280, 17823-17830. doi: 10.1074/jbc.M408646200

Cooper, D. S., Yang, H. S., He, P., Kim, E., Rajbhandari, I., Yun, C. C., et al. (2009). Sodium/bicarbonate cotransporter NBCn1/slc4a7 increases cytotoxicity in magnesium depletion in primary cultures of hippocampal neurons. Eur. J. Neurosci. 29, 437-446. doi: 10.1111/j.1460-9568.2008.06611.x

Crowley, S. D., Gurley, S. B., Herrera, M. J., Ruiz, P., Griffiths, R., Kumar, A. P., et al. (2006). Angiotensin II causes hypertension and cardiac hypertrophy through its receptors in the kidney. Proc. Natl. Acad. Sci. U.S.A. 103, 17985-17990. doi: 10.1073/pnas. 0605545103

Crowley, S. D., Gurley, S. B., Oliverio, M. I., Pazmino, A. K., Griffiths, R., Flannery, P. J., et al. (2005). Distinct roles for the kidney and systemic tissues in blood pressure regulation by the renin-angiotensin system. J. Clin. Invest. 115, 1092-1099. doi: $10.1172 / \mathrm{JCI} 23378$

Dagher, G., and Sauterey, C. (1992). $\mathrm{H}^{+}$pump and $\mathrm{Na}^{+}-\mathrm{H}^{+}$exchange in isolated single proximal tubules of spontaneously hypertensive rats. J. Hypertens. 10, 969-978. doi: 10.1097/00004872-199209000-00009

Damkier, H. H., Brown, P. D., and Praetorius, J. (2010). Epithelial pathways in choroid plexus electrolyte transport. Physiology (Bethesda) 25, 239-249. doi: 10.1152/physiol.00011.2010

Damkier, H. H., Nielsen, S., and Praetorius, J. (2007). Molecular expression of SLC4-derived $\mathrm{Na}^{+}$-dependent anion transporters in selected human tissues. Am. J. Physiol. Regul. Integr. Comp. Physiol. 293, R2136-R2146. doi: 10.1152/ajpregu.00356.2007

Danielsen, A. A., Parker, M. D., Lee, S., Boron, W. F., Aalkjaer, C., and Boedtkjer, E. (2013). Splice cassette II of NBCn1 (slc4a7) interacts with calcineurin A: implications for transporter activity and intracellular $\mathrm{pH}$ control during rat artery contractions. J. Biol. Chem. 288, 8146-8155. doi: 10.1074/jbc.M113.455386

Deitmer, J. W., and Schlue, W. R. (1989). An inwardly directed electrogenic sodiumbicarbonate co-transport in leech glial cells. J. Physiol. 411, 179-194.

Eaton, D. C., Hamilton, K. L., and Johnson, K. E. (1984). Intracellular acidosis blocks the basolateral Na-K pump in rabbit urinary bladder. Am. J. Physiol. 247, F946-F954.

Ehret, G. B., Munroe, P. B., Rice, K. M., Bochud, M., Johnson, A. D., Chasman, D. I., et al. (2011). Genetic variants in novel pathways influence blood pressure and cardiovascular disease risk. Nature 478, 103-109. doi: 10.1038/nature10405

Esler, M., Jackman, G., Bobik, A., Leonard, P., Kelleher, D., Skews, H., et al. (1981). Norepinephrine kinetics in essential hypertension. Defective neuronal uptake of norepinephrine in some patients. Hypertension 3, 149-156. doi: 10.1161/01.HYP.3.2.149

Fakler, B., Schultz, J. H., Yang, J., Schulte, U., Brandle, U., Zenner, H. P., et al. (1996). Identification of a titratable lysine residue that determines sensitivity of kidney potassium channels (ROMK) to intracellular pH. EMBO J. 15 , 4093-4099.

Fleckenstein, A., Frey, M., Zorn, J., and Fleckenstein-Grun, G. (1985). Experimental basis of the long-term therapy of arterial hypertension with calcium antagonists. Am. J. Cardiol. 56, 3H-14H. doi: 10.1016/0002-9149(85)90537-5

Folkow, B., Grimby, G., and Thulesius, O. (1958). Adaptive structural changes of the vascular walls in hypertension and their relation to the control of the peripheral resistance. Acta Physiol. Scand. 44, 255-272. doi: 10.1111/j.17481716.1958.tb01626.x

Gesek, F. A., and Schoolwerth, A. C. (1991). Insulin increases $\mathrm{Na}^{+}-\mathrm{H}^{+}$exchange activity in proximal tubules from normotensive and hypertensive rats. Am. J. Physiol. 260, F695-F703.

Grichtchenko, I. I., Choi, I., Zhong, X., Bray-Ward, P., Russell, J. M., and Boron, W. F. (2001). Cloning, characterization, and chromosomal mapping of a human electroneutral $\mathrm{Na}^{+}$-driven $\mathrm{Cl}-\mathrm{HCO}_{3}$ exchanger. J. Biol. Chem. 276, 8358-8363. doi: 10.1074/jbc.C000716200 
Gröger, N., Vitzthum, H., Frohlich, H., Kruger, M., Ehmke, H., Braun, T., et al. (2012). Targeted mutation of SLC4A5 induces arterial hypertension and renal metabolic acidosis. Hum. Mol. Genet. 21, 1025-1036. doi: 10.1093/hmg/ddr533

Groneberg, D., Konig, P., Wirth, A., Offermanns, S., Koesling, D., and Friebe, A. (2010). Smooth muscle-specific deletion of nitric oxide-sensitive guanylyl cyclase is sufficient to induce hypertension in mice. Circulation 121, 401-409. doi: 10.1161/CIRCULATIONAHA.109.890962

Guilluy, C., Bregeon, J., Toumaniantz, G., Rolli-Derkinderen, M., Retailleau, K., Loufrani, L., et al. (2010). The Rho exchange factor Arhgef1 mediates the effects of angiotensin II on vascular tone and blood pressure. Nat. Med. 16, 183-190. doi: $10.1038 / \mathrm{nm} .2079$

Guyton, A. C. (1990). The surprising kidney-fluid mechanism for pressure controlits infinite gain! Hypertension 16, 725-730. doi: 10.1161/01.HYP.16.6.725

Guyton, A. C. (1991). Blood pressure control-special role of the kidneys and body fluids. Science 252, 1813-1816. doi: 10.1126/science.2063193

Harrison, D. G. (2013). The mosaic theory revisited: common molecular mechanisms coordinating diverse organ and cellular events in hypertension. J. Am. Soc. Hypertens. 7, 68-74. doi: 10.1016/j.jash.2012.11.007

Havenga, M. J., Bosman, G. J., Appelhans, H., and De Grip, W. J. (1994). Expression of the anion exchanger (AE) gene family in human brain. Identification of a new AE protein: AE0. Brain Res. Mol. Brain Res. 25, 97-104. doi: 10.1016/0169328X(94)90283-6

Hayashi, M., Yoshida, T., Monkawa, T., Yamaji, Y., Sato, S., and Saruta, T. (1997). $\mathrm{Na}^{+} / \mathrm{H}^{+}$-exchanger 3 activity and its gene in the spontaneously hypertensive rat kidney. J. Hypertens. 15, 43-48.

He, W. Q., Qiao, Y. N., Zhang, C. H., Peng, Y. J., Chen, C., Wang, P., et al. (2011). Role of myosin light chain kinase in regulation of basal blood pressure and maintenance of salt-induced hypertension. Am. J. Physiol. Heart Circ. Physiol. 301, H584-H591. doi: 10.1152/ajpheart.01212.2010

Hentschke, M., Wiemann, M., Hentschke, S., Kurth, I., Hermans-Borgmeyer, I., Seidenbecher, T., et al. (2006). Mice with a targeted disruption of the $\mathrm{Cl}^{-} / \mathrm{HCO}_{3}^{-}$exchanger AE3 display a reduced seizure threshold. Mol. Cell. Biol. 26, 182-191. doi: 10.1128/MCB.26.1.182-191.2006

Heusser, K., Tank, J., Engeli, S., Diedrich, A., Menne, J., Eckert, S., et al. (2010). Carotid baroreceptor stimulation, sympathetic activity, baroreflex function, and blood pressure in hypertensive patients. Hypertension 55, 619-626. doi: 10.1161/HYPERTENSIONAHA.109.140665

Humar, R., Zimmerli, L., and Battegay, E. (2009). Angiogenesis and hypertension: an update. J. Hum. Hypertens. 23, 773-782. doi: 10.1038/jhh.2009.63

Hunt, S. C., Xin, Y., Wu, L. L., Cawthon, R. M., Coon, H., Hasstedt, S. J., et al. (2006). Sodium bicarbonate cotransporter polymorphisms are associated with baseline and 10-year follow-up blood pressures. Hypertension 47, 532-536. doi: 10.1161/01.HYP.0000196949.26088.3c

Iwai, N., Kajimoto, K., Kokubo, Y., and Tomoike, H. (2006). Extensive genetic analysis of 10 candidate genes for hypertension in Japanese. Hypertension 48, 901-907. doi: 10.1161/01.HYP.0000242485.23148.bb

Izzard, A. S., and Heagerty, A. M. (1989). The measurement of internal pH in resistance arterioles: evidence that intracellular $\mathrm{pH}$ is more alkaline in SHR than WKY animals. J. Hypertens. 7, 173-180. doi: 10.1097/00004872-19890300000002

Jacobs, S., Ruusuvuori, E., Sipila, S. T., Haapanen, A., Damkier, H. H., Kurth, I., et al. (2008). Mice with targeted Slc4a10 gene disruption have small brain ventricles and show reduced neuronal excitability. Proc. Natl. Acad. Sci. U.S.A. 105, 311-316. doi: 10.1073/pnas.0705487105

Jacques, T., Picard, N., Miller, R. L., Riemondy, K. A., Houillier, P., Sohet, F., et al. (2013). Overexpression of pendrin in intercalated cells produces chloride-sensitive hypertension. J. Am. Soc. Nephrol. 24, 1104-1113. doi: 10.1681/ASN.2012080787

Kobayashi, K., Monkawa, T., Hayashi, M., and Saruta, T. (2004). Expression of the $\mathrm{Na}^{+} / \mathrm{H}^{+}$exchanger regulatory protein family in genetically hypertensive rats. J. Hypertens. 22, 1723-1730. doi: 10.1097/00004872-200409000-00016

Kokubo, Y., Tomoike, H., Tanaka, C., Banno, M., Okuda, T., Inamoto, N., et al. (2006). Association of sixty-one non-synonymous polymorphisms in forty-one hypertension candidate genes with blood pressure variation and hypertension. Hypertens. Res. 29, 611-619. doi: 10.1291/hypres.29.611

Kozak, J. A., Matsushita, M., Nairn, A. C., and Cahalan, M. D. (2005). Charge screening by internal $\mathrm{pH}$ and polyvalent cations as a mechanism for activation, inhibition, and rundown of TRPM7/MIC channels. J. Gen. Physiol. 126, 499-514. doi: 10.1085/jgp.200509324
Kunes, J., Leontjeva, G. R., Byskova, E., Pohlova, I., Govyrin, V. A., and Zicha, J. (1991). Adrenergic innervation of blood vessels in Dahl rats with salt hypertension. Clin. Exp. Hypertens. A 13, 1343-1355. doi: 10.3109/10641969109048797

Lund-Johansen, P. (1991). Essential hypertension: hemodynamic and therapeutic changes over 20 years. J. Cardiovasc. Pharmacol. 18(Suppl. 4), S1-S7. doi: 10.1097/00005344-199118041-00002

Majumdar, D., Maunsbach, A. B., Shacka, J. J., Williams, J. B., Berger, U. V., Schultz, K. P., et al. (2008). Localization of electrogenic Na/bicarbonate cotransporter NBCe1 variants in rat brain. Neuroscience 155, 818-832. doi: 10.1016/j.neuroscience.2008.05.037

Mangiarua, E. I., and Lee, R. M. (1990). Increased sympathetic innervation in the cerebral and mesenteric arteries of hypertensive rats. Can. J. Physiol. Pharmacol. 68, 492-499. doi: 10.1139/y90-070

Mathiassen, O. N., Buus, N. H., Sihm, I., Thybo, N. K., Morn, B., Schroeder, A. P., et al. (2007). Small artery structure is an independent predictor of cardiovascular events in essential hypertension. J. Hypertens. 25, 1021-1026. doi: 10.1097/HJH.0b013e32805bf8ed

Morduchowicz, G. A., Sheikh-Hamad, D., Jo, O. D., Nord, E. P., Lee, D. B., and Yanagawa, N. (1989). Increased $\mathrm{Na}^{+} / \mathrm{H}^{+}$antiport activity in the renal brush border membrane of SHR. Kidney Int. 36, 576-581. doi: 10.1038/ki.1989.233

Morrison, A. C., Srinivas, S. K., Elovitz, M. A., and Puschett, J. B. (2010). Genetic variation in solute carrier genes is associated with preeclampsia. Am. J. Obstet. Gynecol. 203, 491.e1-491.e13. doi: 10.1016/j.ajog.2010.06.004

Nielsen, H., Aalkjaer, C., and Mulvany, M. J. (1991). Differential contractile effects of changes in carbon dioxide tension on rat mesenteric resistance arteries precontracted with noradrenaline. Pflugers Arch. 419, 51-56. doi: 10.1007/BF00373747

Nielsen, H., Hasenkam, J. M., Pilegaard, H. K., Aalkjaer, C., and Mortensen, F. V. (1992). Age-dependent changes in alpha-adrenoceptor-mediated contractility of isolated human resistance arteries. Am J. Physiol. 263, H1190-H1196.

Noonan, W. T., Woo, A. L., Nieman, M. L., Prasad, V., Schultheis, P. J., Shull, G. E., et al. (2005). Blood pressure maintenance in NHE3-deficient mice with transgenic expression of NHE3 in small intestine. Am. J. Physiol. Regul. Integr. Comp. Physiol. 288, R685-R691. doi: 10.1152/ajpregu.00209.2004

Orlov, S. N., Adarichev, V. A., Devlin, A. M., Maximova, N. V., Sun, Y. L., Tremblay, J., et al. (2000). Increased $\mathrm{Na}^{+} / \mathrm{H}^{+}$exchanger isoform 1 activity in spontaneously hypertensive rats: lack of mutations within the coding region of NHE1. Biochim. Biophys. Acta 1500, 169-180. doi: 10.1016/S0925-4439(99)00101-5

Page, I. H. (1949). Pathogenesis of arterial hypertension. JAMA 140, 451-458. doi: 10.1001/jama.1949.02900400005002

Pedersen, S. F. (2006). The $\mathrm{Na}^{+} / \mathrm{H}^{+}$exchanger NHE1 in stress-induced signal transduction: implications for cell proliferation and cell death. Pflugers Arch. 452, 249-259. doi: 10.1007/s00424-006-0044-y

Pedrosa, R., Goncalves, N., Hopfer, U., Jose, P. A., and Soares-da-Silva, P. (2007). Activity and regulation of $\mathrm{Na}^{+}-\mathrm{HCO}_{3}^{-}$cotransporter in immortalized spontaneously hypertensive rat and Wistar-Kyoto rat proximal tubular epithelial cells. Hypertension 49, 1186-1193. doi: 10.1161/HYPERTENSIONAHA.106.083444

Pelham, C. J., Keen, H. L., Lentz, S. R., and Sigmund, C. D. (2013). Dominant negative PPARg promotes atherosclerosis, vascular dysfunction, and hypertension through distinct effects in endothelium and vascular muscle. Am. J. Physiol. Regul. Integr. Comp. Physiol. 304, R690-R701. doi: 10.1152/ajpregu.00607.2012

Restini, C. A., and Bendhack, L. M. (2006). Involvement of non-selective $\mathrm{Ca}^{2+}$ channels in the contraction induced by alkalinization of rat anococcygeus muscle cells. Eur. J. Pharmacol. 553, 288-296. doi: 10.1016/j.ejphar.2006.10.024

Rickmann, M., Orlowski, B., Heupel, K., and Roussa, E. (2007). Distinct expression and subcellular localization patterns of $\mathrm{Na}^{+} / \mathrm{HCO}_{3}^{-}$cotransporter (SLC 4A4) variants NBCe1-A and NBCe1-B in mouse brain. Neuroscience 146, 1220-1231. doi: 10.1016/j.neuroscience.2007.02.061

Rizzoni, D., Porteri, E., Boari, G. E., De Ciuceis, C., Sleiman, I., Muiesan, M. L., et al. (2003). Prognostic significance of small-artery structure in hypertension. Circulation 108, 2230-2235. doi: 10.1161/01.CIR.0000095031.51492.C5

Ro, H. A., and Carson, J. H. (2004). pH microdomains in oligodendrocytes. J. Biol. Chem. 279, 37115-37123. doi: 10.1074/jbc.M403099200

Ruminot, I., Gutierrez, R., Pena-Munzenmayer, G., Anazco, C., Sotelo-Hitschfeld, T., Lerchundi, R., et al. (2011). NBCel mediates the acute stimulation of astrocytic glycolysis by extracellular $\mathrm{K}^{+}$. J. Neurosci. 31, 14264-14271. doi: 10.1523/JNEUROSCI.2310-11.2011

Russell, J. M., and Boron, W. F. (1976). Role of choloride transport in regulation of intracellular pH. Nature 264, 73-74. doi: 10.1038/264073a0 
Russell, J. M., Boron, W. F., and Brodwick, M. S. (1983). Intracellular pH and Na fluxes in barnacle muscle with evidence for reversal of the ionic mechanism of intracellular pH regulation. J. Gen. Physiol. 82, 47-78. doi: 10.1085/jgp.82.1.47

Schultheis, P. J., Clarke, L. L., Meneton, P., Miller, M. L., Soleimani, M., Gawenis, L. R., et al. (1998). Renal and intestinal absorptive defects in mice lacking the NHE3 $\mathrm{Na}^{+} / \mathrm{H}^{+}$exchanger. Nat. Genet. 19, 282-285. doi: 10.1038/969

Schwab, A., Fabian, A., Hanley, P. J., and Stock, C. (2012). Role of ion channels and transporters in cell migration. Physiol. Rev. 92, 1865-1913. doi: 10.1152/physrev.00018.2011

Schwiening, C. J., and Boron, W. F. (1994). Regulation of intracellular pH in pyramidal neurones from the rat hippocampus by $\mathrm{Na}^{+}$-dependent $\mathrm{Cl}^{-}-\mathrm{HCO}_{3}^{-}$ exchange. J. Physiol. 475, 59-67.

Scuteri, A., Jensen, P. E., and Aalkjaer, C. (1995). The regulation of pH in resistance arteries from spontaneously hypertensive and Wistar-Kyoto rats: the effect of bicarbonate. J. Hypertens. 13, 523-528. doi: 10.1097/00004872-19950500000007

Shrode, L. D., and Putnam, R. W. (1994). Intracellular $\mathrm{pH}$ regulation in primary rat astrocytes and C6 glioma cells. Glia 12, 196-210. doi: 10.1002/glia.440120305

Singh, A. K., Amlal, H., Haas, P. J., Dringenberg, U., Fussell, S., Barone, S. L., et al. (2008). Fructose-induced hypertension: essential role of chloride and fructose absorbing transporters PAT1 and Glut5. Kidney Int. 74, 438-447. doi: 10.1038/ki.2008.184

Sivertsson, R. (1970). The hemodynamic importance of structural vascular changes in essential hypertension. Acta Physiol. Scand. Suppl. 343, 1-56.

Sõber, S., Org, E., Kepp, K., Juhanson, P., Eyheramendy, S., Gieger, C., et al. (2009). Targeting 160 candidate genes for blood pressure regulation with a genomewide genotyping array. PLOS ONE 4:e6034. doi: 10.1371/journal.pone.0006034

Sonalker, P. A., Tofovic, S. P., Bastacky, S. I., and Jackson, E. K. (2008). Chronic noradrenaline increases renal expression of NHE-3, NBC-1, BSC-1 and aquaporin-2. Clin. Exp. Pharmacol. Physiol. 35, 594-600. doi: 10.1111/j.14401681.2007.04846.x

Sonalker, P. A., Tofovic, S. P., and Jackson, E. K. (2004). Increased expression of the sodium transporter BSC-1 in spontaneously hypertensive rats. J. Pharmacol. Exp. Ther. 311, 1052-1061. doi: 10.1124/jpet.104.071209

Stock, C., and Schwab, A. (2006). Role of the Na/H exchanger NHE1 in cell migration. Acta Physiol. (Oxf). 187, 149-157. doi: 10.1111/j.1748-1716.2006.01543.x

Svichar, N., Esquenazi, S., Chen, H. Y., and Chesler, M. (2011). Preemptive regulation of intracellular $\mathrm{pH}$ in hippocampal neurons by a dual mechanism of depolarization-induced alkalinization. J. Neurosci. 31, 6997-7004. doi: 10.1523/JNEUROSCI.6088-10.2011

Symplicity HTN-1 Investigators. (2011). Catheter-based renal sympathetic denervation for resistant hypertension: durability of blood pressure reduction out to 24 months. Hypertension 57, 911-917. doi: 10.1161/HYPERTENSIONAHA.110.163014

Taylor, J. Y., Maddox, R., and Wu, C. Y. (2009). Genetic and environmental risks for high blood pressure among African American mothers and daughters. Biol. Res. Nurs. 11, 53-65. doi: 10.1177/1099800409334817

Taylor, J. Y., Sampson, D., Taylor, A. D., Caldwell, D., and Sun, Y. V. (2013). Genetic and BMI risks for predicting blood pressure in three generations of West African Dogon women. Biol. Res. Nurs. 15, 105-111. doi: 10.1177/1099800411 419026

Taylor, J. Y., Wu, C. Y., Darling, D., Sun, Y. V., Kardia, S. L., and Jackson, J. S. (2012). Gene-environment effects of SLC4A5 and skin color on blood pressure among African American women. Ethn. Dis. 22, 155-161.

Thomas, R. C. (1976). Ionic mechanism of the $\mathrm{H}^{+}$pump in a snail neurone. Nature 262, 54-55. doi: 10.1038/262054a0
Thomsen, A. B. K., Kim, S., Aalbaek, F., Aalkjaer, C., and Boedtkjer, E. (2013). Intracellular acidification alters myogenic responsiveness and vasomotion of mouse middle cerebral arteries. J. Cereb. Blood Flow Metab. doi: 10.1038/jcbfm.2013.192. [Epub ahead of print].

Tolkovsky, A. M., and Richards, C. D. (1987). $\mathrm{Na}^{+} / \mathrm{H}^{+}$exchange is the major mechanism of $\mathrm{pH}$ regulation in cultured sympathetic neurons: measurements in single cell bodies and neurites using a fluorescent $\mathrm{pH}$ indicator. Neuroscience 22, 1093-1102. doi: 10.1016/0306-4522(87)92984-8

Verlander, J. W., Hassell, K. A., Royaux, I. E., Glapion, D. M., Wang, M. E., Everett, L. A., et al. (2003). Deoxycorticosterone upregulates PDS (Slc26a4) in mouse kidney: role of pendrin in mineralocorticoid-induced hypertension. Hypertension 42, 356-362. doi: 10.1161/01.HYP.0000088321.67254.B7

Wall, S. M., Kim, Y. H., Stanley, L., Glapion, D. M., Everett, L. A., Green, E. D., et al. (2004). $\mathrm{NaCl}$ restriction upregulates renal Slc26a4 through subcellular redistribution: role in $\mathrm{Cl}^{-}$conservation. Hypertension 44, 982-987. doi: 10.1161/01.HYP.0000145863.96091.89

Wang, W. H., Schwab, A., and Giebisch, G. (1990). Regulation of smallconductance $\mathrm{K}^{+}$channel in apical membrane of rat cortical collecting tubule. Am. J. Physiol. 259, F494-F502.

WHO. (2013). A Global Brief on Hypertension. Geneva: World Health Organization. Wirth, A., Benyo, Z., Lukasova, M., Leutgeb, B., Wettschureck, N., Gorbey, S., et al. (2008). $\mathrm{G}_{12}-\mathrm{G}_{13}$-LARG-mediated signaling in vascular smooth muscle is required for salt-induced hypertension. Nat. Med. 14, 64-68. doi: 10.1038/nm1666

Yang, H. C., Liang, Y. J., Chen, J. W., Chiang, K. M., Chung, C. M., Ho, H. Y., et al. (2012). Identification of IGF1, SLC4A4, WWOX, and SFMBT1 as hypertension susceptibility genes in Han Chinese with a genome-wide gene-based association study. PLoS ONE 7:e32907. doi: 10.1371/journal.pone.0032907

Yu, L., Quinn, D. A., Garg, H. G., and Hales, C. A. (2008). Deficiency of the NHE1 gene prevents hypoxia-induced pulmonary hypertension and vascular remodeling. Am. J. Respir. Crit. Care Med. 177, 1276-1284. doi: 10.1164/rccm.2007101522OC

Zhang, J., Ren, C., Chen, L., Navedo, M. F., Antos, L. K., Kinsey, S. P., et al. (2010). Knockout of $\mathrm{Na}^{+} / \mathrm{Ca}^{2+}$ exchanger in smooth muscle attenuates vasoconstriction and L-type $\mathrm{Ca}^{2+}$ channel current and lowers blood pressure. Am. J. Physiol. Heart Circ. Physiol. 298, H1472-H1483. doi: 10.1152/ajpheart. 00964.2009

Conflict of Interest Statement: The authors declare that the research was conducted in the absence of any commercial or financial relationships that could be construed as a potential conflict of interest.

Received: 16 September 2013; accepted: 09 December 2013; published online: 24 December 2013.

Citation: Boedtkjer E and Aalkjaer C (2013) Disturbed acid-base transport: an emerging cause of hypertension. Front. Physiol. 4:388. doi: 10.3389/fphys.2013.00388 This article was submitted to Membrane Physiology and Membrane Biophysics, a section of the journal Frontiers in Physiology.

Copyright (c) 2013 Boedtkjer and Aalkjaer. This is an open-access article distributed under the terms of the Creative Commons Attribution License (CC BY). The use, distribution or reproduction in other forums is permitted, provided the original author(s) or licensor are credited and that the original publication in this journal is cited, in accordance with accepted academic practice. No use, distribution or reproduction is permitted which does not comply with these terms. 